\title{
Challenges Facing the New President in the Greater Middle East
}

In November 2008, students, scholars, and interested citizens convened in East Lansing to hear experts speak about the Middle East. This event, "Challenges Facing the New President in the Greater Middle East," was hosted by Michigan State University's Muslim Studies Program with generous cosponsorship by the Institute for Social Policy and Understanding (ISPU) and the Association of Muslim Social Scientists of North America (AMSS). Speakers highlighted the topic's timeliness, given the current global political climate. Experts agreed that by heeding the nuances surrounding Middle Eastern issues and contextualizing them, a positive transformation of American policy can be achieved.

Professor Mohammed Ayoob (Michigan State University) articulated why the Middle East is significant: as the Muslim world's spiritual and political heartland, understanding its politics is essential to understanding that world's politics, and being the home of more than $60 \%$ of the world's proven oil reserves and $40 \%$ of its natural gas makes it strategically important. This overview contextualized the challenges facing the Obama administration on such critical regional issues as political Islam, the Israeli-Palestinian conflict, and the Iraq War as well as the United States' tenuous relations with Pakistan, Afghanistan, Iran, and Saudi Arabia.

Christine Fair (RAND Corporation) analyzed American challenges in Pakistan and Afghanistan. She noted that the American-Pakistani relationship's greatest problem is that the United States has seemed unable to lucidly determine its interests in Pakistan. She also criticized its ongoing aid to the Pakistani military, which continues to function ineffectively and remains a hotbed of anti-Americanism. This aid also precludes efforts to engage with Pakistani civilians, an undertaking that she considered crucial 
to fostering more mutually beneficial relations. Similarly, Fair promoted greater engagement with Afghans in order to improve American-Afghan relations and identified the Afghan Parliament as a critical actor that the United States has neglected.

Dr. Ali Ansari (University of St. Andrews) identified three factors underlying American-Iranian political tensions: the lack of engagement on core issues, the failure to consider the perspectives of ordinary Iranians, and a mismatch in the willingness to engage. Positing that overcoming this political impasse is essential, because Iran is the region's lynchpin, he recommended that the United States wean itself off its dependence on hard power and instead utilize a broader range of tools. In addition, American policymakers need to acquire a greater awareness about Iran. Ansari concluded that the prevalence of jingoistic policymakers has impeded efforts to foster meaningful engagement.

Saudi Arabia is the region's only other self-proclaimed Islamic state, and yet it and Iran have starkly different relations with the United States. Joseph Kechichian (Middle East Institute) explained that the long-standing American-Saudi alliance is predicated upon the exchange of oil for security; however, this relationship has been challenged since 9/11. He noted that although an anti-Saudi industry is thriving in Washington, the necessity of mutual engagement has perhaps never been greater.

One issue of particular relevance to most (if not all) other countries in the region is political Islam. Farid Senzai (ISPU) chaired this panel, with remarks made by Geneive Abdo (Century Foundation). Abdo reviewed the question of American engagement with proponents of political Islam and stressed that widespread ignorance on this topic is found among laypeople and policymakers alike. Both Ayoob and Abdo also noted that viewing political Islam as antithetical to American interests is a relatively recent phenomenon.

One reason why the United States has been reluctant to engage with Islamists is uncertainty about their true objectives. For example, the Muslim Brotherhood in Egypt articulated in 2007 that no woman or non-Muslim could become president if their group ever rose to power. This example illustrates why the United States still questions some Islamists, despite their renunciation of violence and democratic leanings.

She also outlined three policy options available to the Obama administration: no direct engagement, no engagement with Islamists but instead a reliance on the ostensible moderate Muslim majority, and support of local NGOs to fortify development efforts. The Bush administration adopted the latter two approaches. Abdo, however, criticized the second approach 
(which was manifested in public diplomacy efforts) as inherently flawed for providing only cosmetic solutions to deeper problems.

Daniel Levy (Century Foundation), who addressed the Arab-Israeli conflict, stressed that the possibility of a two-state solution will disappear if it does not occur during the next administration and that a two-state solution is the only durable outcome. From his perspective, the Obama administration may have difficulty resolving the conflict if it relies upon the Annapolis process. Levy instead recommended a comprehensive solution that utilizes the Arab peace initiative, promotes more American involvement, and encourages internal Palestinian reconciliation. He concluded on a hopeful remark: despite being subject to hatemongering during this election, American Jews voted overwhelmingly for Obama. Therefore, there is great potential to mobilize this community toward a permanent resolution.

Iraq was the focus of Stephen Negus (Woodrow Wilson Center). According to him, the greatest challenge is withdrawing American troops without compromising the notable political and security-related progress that has been made. He stated that the Sunni insurgency, which is largely responsible for the ongoing instability, is becoming less popular among Iraqis and thus provides great opportunity. He also questioned the feasibility of maintaining the American military in Iraq for much longer, given its overstretched resources and extensive public support for withdrawal.

Shibley Telhami (University of Maryland) concluded the conference by highlighting the role of public opinion. Regional public opinion can either hinder or foster the United States' ability to tackle regional concerns and improve its relations with states.

Overall, many speakers asserted that more meaningful engagement is necessary to establish an effective American policy. Of particular importance is acknowledging public opinion and engaging with actors who are legitimate in the eyes of their constituents. The experts also reiterated that substantial policy modifications, as opposed to superficial solutions, are needed. These recommendations can help formulate a strategy for the Obama administration that will improve the United States' status in the Middle East. 